\title{
A clinical study of relationship between obesity and pubertal development in girls
}

\author{
Phil Soo Oh${ }^{1 *}$, Hui Kwon Kim', Jeh Hoon Shin ${ }^{2}$ \\ From 7th APPES Biennial Scientific Meeting \\ Nusa Dua, Bali. 14-17 November 2012
}

\section{Purpose}

Recently, public interests for obesity and earlier pubertal development has been increasing. The purpose of this study was to analyze the relationship between obesity and pubertal development in girls.

\section{Methods}

This study was performed for 158 girls with earlier pubertal development from July 2008 to June 2010. Their mean age was $8.27 \pm 1.3$ years and mean bone age advancement was $1.86 \pm 0.3$ years.

\section{Results}

1. Upon the weight-for-height percentiles, their obesity rate was $9.2 \%$ and overweight rate $15.8 \%$. However, upon BMI the result was a little different, that is, their obesity rate is $13.2 \%$ and overweight rate is $24.3 \%$. 2 . About $40 \%$ of the girls had a family history of early maturation. Among them, $25.7 \%$ had a maternal history, $4.6 \%$ paternal and $7.2 \%$ both. However, $60 \%$ of them had no family history. 3 . We then classified these girls into the families with one daughter and one son and those with two daughters. In one-daughter/one-son families, $65.3 \%$ were the first children and $30.8 \%$ were seconds. In two-daughters families, $65.3 \%$ were the firsts and $34.7 \%$ were seconds. 4 . We found that $67.5 \%$ had a history of taking herbal medicine materials.

\section{Conclusions}

The obesity and overweight rate in girls with earlier pubertal development was higher than the age-matched normal females, but with a little discrepancy between weight-for-height percentile and BMI-based data. And, it seems to be possible that herbal medicine materials is

${ }^{1}$ Department of Pediatrics, Hallym University Medical Center, Chuncheon, Korea

Full list of author information is available at the end of the article a potential factor for earlier pubertal development in Korea.

\section{Authors' details}

${ }^{1}$ Department of Pediatrics, Hallym University Medical Center, Chuncheon, Korea. ${ }^{2}$ Department of Pediatrics, Hanyang University Medical Center, Seoul, Korea.

Published: 3 October 2013

\section{doi:10.1186/1687-9856-2013-S1-P76}

Cite this article as: Oh et al:: A clinical study of relationship between obesity and pubertal development in girls. International Journal of Pediatric Endocrinology 2013 2013(Suppl 1):P76.
Submit your next manuscript to BioMed Central and take full advantage of:

- Convenient online submission

- Thorough peer review

- No space constraints or color figure charges

- Immediate publication on acceptance

- Inclusion in PubMed, CAS, Scopus and Google Scholar

- Research which is freely available for redistribution

\section{() Biomed Central}

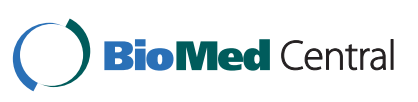

